\title{
Optimalisasi Perpustakaan Desa Untuk Meningkatkan Budaya Literasi di Desa Jatiadi, Kabupaten Probolinggo
}

\author{
Mutinda Teguh Widayanto*1, Tim KKN Desa Jatiadi ${ }^{2}$ \\ ${ }^{1,2}$ Program Studi Manajemen, Fakultas Ekonomi, Universitas Panca Marga, Probolingo \\ J1. Yos Sudarso Probolinggo, Jawa Timur 67271 (0335) 422715 \\ e-mail: "mutindateguh@upm.ac.id
}

Informasi Artikel

Diterima Redaksi : 22 Desember 2019

Revisi Akhir : 28 Januari 2020

Diterbitkan Online : 31 Januari 2020

Kata Kunci :

Perpustakaan Desa, Budaya Literasi

\section{PENDAHULUAN}

Salah satu cita cita kemerdekaan bangsa Indonesia yang tercantum pada pembukaan UUD 1945 adalah mencerdaskan kehidupan bangsa. Berbagai upaya telah dilakukan pemerintah dengan sebagai upaya untuk mewujudkan cita cita tersebut. Disamping penyelenggaraan pendidikan nasional dengan berbagai tingkatan, bangkitnya kesadaran dari masyarakat untuk senantiasa meningkatkan penge-tahuan juga akan mendorong upaya pencapaian tujuan tersebut. Kemampuan membaca serta menulis atau yang biasa disebut literasi adalah tahap awal dari proses pendidikan guna mencerdaskan kehidupan bangsa. Salah satu upaya untuk membangkitkan

\section{Abstrak}

Kemajuan suatu bangsa sangat ditentukan oleh sejauh mana masyarakatnya mempunyai kesadaran untuk meningkatkan pengetahuannya. Peningkatan pengetahuan masyarakat, disamping ditentukan oleh pendidikan formal juga akan sangat terbantu jika masyarakat mempunyai budaya literasi yang baik. Untuk mengembangkan budaya literasi bagi seluruh bidang pendidikan (sekolah, keluarga, dan masyarakat), maka mulai tahun 2016 Pemerintah menggiatkan Gerakan Literasi Nasional (GLN). Keberadaan perpustakaan desa akan sangat membantu gerakan ini. Desa Jatiadi, Kecamatan Gending Kabupaten Probolinggo sudah memiliki perpustakaan desa, namun keberadaannya masih belum representatif untuk bisa mendorong masyarakat untuk memanfaatkannya. Melalui Kegiatan Kuliah kerja Nyata, dilakukan kegiatan Pengabdian Masyarakat berupa Optimalisasi Perpustakaan Desa yang dilakukan dengan metode penambahan koleksi buku, pembenahan sistem perpustakaan dan sosialisasi pemanfaatan perpustakaan desa kepada masyarakat. Diharapkan kegiatan ini dapat mendorong meningkatnya budaya literasi masyarakat sehingga masyarakat bisa mendapatkan informasi dan pengetahuan yang mereka butuhkan yang bermanfaat bagi peningkatan kualitas serta taraf hidup mereka.

budaya literasi tersebut adalah melalui perpustakaan.

Pemerintah telah mengembangkan perpustakaan memalui berbagai departemen terkait. Dari berbagai jenis perpustakaan yang dikeloka oleh pemerintah pusat, pemerintah daerah, berbagai institusi pendidikan, terdapat pula perpustakaan desa yang dikelola oleh pemerintahan desa. Perpustakaan Desa memiliki peranan yang cukup strategis guna menumbuhkan minat baca dan budaya literasi pada masyarakat, karena Pemerintah Desa adalah merupakan satuan unit pemerintahan yang paling kecil yang bersinggungan langsung dengan masyarakat. Selain itu, sebagian besar masyarakat Indonesia tinggal di daerah pedesaan dan pengguna dari perpustakaan desa ini tidak dibatasi oleh tingkat

Mutinda Teguh "Optimalisasi Perpustakaan Desa untuk Meningkatkan

Budaya Literasi di Desa Jatiadi, Kabupaten Probolinggo" 
pendidikan, usia dan profesi sehingga dapat menyentuh kepada semua lapisan masyarakat, terutama yang berada di desa. Keberadaan Perpustakaan Desa yang mempunyai peran strategis ini adalah sarana yang cukup efektif untuk me-ningkatkan kesadaran peningkatan pengetahuan melalui membaca.

Pemerintah, melalui Kepmendagri dan Otoda No. 3 Tahun 2001 perihal perpustakaan desa/kelurahan sudah menetapkan bahwa perpustakaan desa harus ditempatkan sebagai penggerak dalam meningkatkan budaya baca dan literasi berbagai informasi utama. Perpustakaan desa juga sebagai institusi informasi yang mempunyai tugas serta peluang yang besar untuk berperan secara aktif dalam usaha mencerdaskan kehidupan bangsa. Keberadaan perpustakaan desa yang representatif akan mendorong masyarakat desa untuk memanfaatkannya untuk meningkatkan pengetahuannya sesuai kebutuhan dan minatnya.

\subsection{Kondisi Mitra}

Desa Jatiadi terletak di Kecamatan Gending Kabupaten Probolinggo memiliki luas administrasi 294,947 Ha, terdiri dari 7 dusun dengan batas wilayah sebelah utara : desa Klaseman, timur : desa Karangpranti, selatan : desa Suko dan barat : desa Brumbungan. Jumlah penduduk sesuai sensus penduduk tahun 2014 adalah sebanyak 3.384 jiwa dengan profesi terbanyak sebagai petani, pedagang, peternak, karyawan, ASN dan profesi lainnya. Prosentase tingkat pendidikan terbesar adalah SD 27,26\%, SLTP 22,34\%, SLTA $19,31 \%$, tidak tamat SD $18,38 \%$ dan Perguruan Tinggi 12,62\%. Lembaga pendidikan formal yang ada adalah untuk tingkat Prasekolah : 4 lembaga, SD : 3 lembaga, SLTP : 2 lembaga dan tingkat SLTA : 1 lembaga.

\subsection{Permasalahan}

Tingkat pendidikan sebagian besar penduduk $(68,07 \%)$ yang hanya tamatan SLTP berimplikasi terhadap masih rendahnya pemahaman masyarakat terhadap aspek-aspek yang berkaitan dengan bidang kehidupan seperti bidang kesehatan, bidang ekonomi, bidang pendidikan serta bidang lainnya. Rendahnya pemahaman tersebut juga berdampak terhadap keberhasilan program pembangunan yang tujuan akhirnya ialah dalam rangka meningkatkan taraf hidup masyarakat. Salah satu usaha untuk meningkatkan pemahaman masyarakat adalah melalui bidang pendidikan yang tidak membatasi tingkat pendidikan atau usia. Keberadaan perpustakaan desa adalah suatu usaha guna meningkatkan pemahaman masyarakat di berbagai bidang sesuai dengan kebutuhan mereka. Di Desa Jatiadi sudah terdaat perpustakaan desa, tetapi masih belum berfungsi secara optimal, dengan permasalahan sebagai berikut :

1. Koleksi buku masih kurang

2. Buku masih belum tertata dengan baik dan teratur

3. Sistem pengelolaan perpustakaan belum berjalan baik

4. Keberadaan dan Fungsi Perpustakaan Desa belum dipahami masyarakat secara optimal

Sedangkan tujuan dari kegiatan ini adalah :

1. Menfungsikan Perpustakaan desa secara optimal.

2. Meningkatkan pemahaman masya-rakat tentang keberadaan dan pen-tingnya perpustakaan desa.

3. Meningkatkan budaya literasi masyarakat melalui pemanfaatan perpustakaan desa.

\subsection{Rencana Pemecahan Masalah}

Untuk menyelesaikan permasalahan yang ada, maka dilakukan kegiatan sebagai berikut :

1. Melakukan penataan koleksi perpustakaan desa sehingga dapat dipergunakan sebagaimana mestinya.

2. Membenahi sistem administrasi perpustakaan dengan sistem perpustakaan yang uptodate.

3. Menambah koleksi buku

4. Mensosialisasikan perpustakaan desa serta manfaatnya kepada masyarakat.

Mutinda Teguh "Optimalisasi Perpustakaan Desa untuk Meningkatkan

Budaya Literasi di Desa Jatiadi, Kabupaten Probolinggo" 


\subsection{Tinjauan Pustaka}

Literasi berasal dari bahasa Latin yaitu litera yang berarti huruf atau juga diaktikan sebagai keaksaraan. Dilihat dari makna aslinya, literasi berarti kemampuan seseorang dalam membaca dan menulis. Selain itu literasi juga memiliki kesamaan arti dengan belajar dan memahami sumber bacaan. Iriantara menyampaikan bahwa saat ini literasi bukan hanya dimaknai sebagai kemampuan dalam membaca dan menulis saja, tetapi saat ini sudah mengalami perluasan makna sehingga mencakup juga objek yang berbentuk visual, audiovisual dan dimensi lainnya [1]. Menurut Dewi Utama, Literasi dapat dimaknai sebagai kemampuan mengakses, memahami, dan mengunakan sesuatu secara cerdas melalui berbagai aktivitas antara lain membaca, melihat, menyimak, menulis atau berbicara [2].

Berdasarkan pendapat-pendapat tersebut maka dapat dijelaskan bahwa literasi adalah peristiwa sosial yang disertai keterampilan untuk menciptakan serta menginter-prestasikan makna melalui teks. Dalam proses Literasi diperlukan kemampuan dalam menyampaikan serta mendapatkan informasi dalam bentuk tulisan. Pada masa globalisasi saait ini, suatu masyarakat dapat dikatakan mempunyai budaya literasi jika masyarakat tersebut sudah dapat meng-gunakan segala informasi yang didapat sehingga mereka dapat meningkatkan pengetahuannya yang bermanfaat dalam kehidupanya. Berdasarka uraian tersebut dapat dikatakan bahwa budaya literasi merupakan suatu tahap dalam perilaku sosial berupa kemampuan seseorang untuk membaca, memahami, dan menganalisis informasi sehingga pengetahuan mereka dapat bermanfaat dalam memecahkan masalah yang muncul dalam kehidupan sehari-hari guna perbaikan kualitas kehidupannya.

Pemerintah, melalui Kemendikbud telah mengupayakan Gerakan Literasi Nasional yang dimulai pada tahun 2016 guna mengembangkan budaya literasi pada semua ranah pendidikan [3]. Tujuan umum Gerakan Literasi Nasional tersebut adalah untuk menumbuhkembangkan budaya dalam literasi di ekosistem pendidikan sejak mulai dari keluarga, sekolah, serta masyarakat sebagai bentuk pembelajaran sepanjang hayat sebagai usaha untuk meningkatkan tingkat kualitas hidup. Bidang atau dimensi Literasi meliputi [3]: Literasi Baca dan Tulis, Literasi Numerasi, Literasi Sains, Literasi Digital, Literasi Finansial dan Literasi Budaya dan Kewargaan. Untuk mewujudkan budaya Literasi, berbagai upaya dilakukan, salah satu ranah dalam Gerakan Literasi Nasional adalah Gerakan literasi masyarakat yang dilakukan melalui penyediaan berbagai bahan bacaan di ruang publik, penguatan fasilitator bagi literasi masyarakat, diperluasnya akses untuk sumber belajar, serta perluasan keterlibatan masyarakat dalam semua bentuk aktivitas literasi.

\subsection{Perpustakaan Desa}

Perpustakaan, sesuai UU No 47 tahun 2007 tentang perpustakaan, adalah institusi pengelola koleksi karya tulis, karya cetak, dan/atau karya rekam secara profesional dengan sistem yang baku guna memenuhi kebutuhan penelitian, pendidikan, pelestarian, rekreasi dan informasi para pemustaka [4].

Perpustakaan umum ialah perpustakaan yang tujuannya diperuntukkan untuk masyarakat luas yang berperan sebagai sarana bagi pembelajaran sepanjang hidup, tanpa membedakan usia, ras, jenis kelamin, agama, suku, dan status ekonomi atau sosial. Dalam Undang-undang tersebut juga dijelaskan bahwa Perpustakaan umum dijalankan oleh Pemerintah pusat, pemerintah provinsi, pemerintah kota atau kabupaten, kecamatan, serta desa, dan dapat diselenggarakan juga oleh masyarakat. Harapan yang ingin dicapai dengan adanya perpustakaan adalah agar Perpustakaan berfungsi sebagai media pendidikan, pelestarian, penelitian, informasi, dan rekreasi dalam rangka meningkatkan tingkat kecerdasan serta keberdayaan bangsa.

Sedangkan Perpustakaan Desa menurut

Mutinda Teguh "Optimalisasi Perpustakaan Desa untuk Meningkatkan

Budaya Literasi di Desa Jatiadi, Kabupaten Probolinggo" 
Peraturan Kepala Perpustakaan Nasional RI No. 6 Tahun 2017 tentang Standar Nasional Perpustakaan Desa / Kelurahan, perpustakaan desa adalah perpustakaan yang diselenggarakan oleh pemerintah desa/ kelurahan yang memiliki tugas pokok untuk melaksanakan pengembangan perpustakaan yang ada di wilayah desa/kelurahan dan melaksanakan layanan perpustakaan bagi masyarakat umum dengan tidak membedakan ras, usia, agama, gender dan status sosial ekonomi [5]. Adapun tujuan perpustakaan desa adalah untuk meningkatkan kualitas serta taraf hidup masyarakat melalui tersedianya bahan perpustakaan atau akses informasi guna meningkatkan keterampilan, ilmu pengetahuan, pendidikan, apresiasi budaya, dan rekreasi bagi kepentingan pembelajaran yang dilakukan sepanjang hayat [6].

Kehadiran perpustakaan desa pada dasarnya milik, dibangun oleh rakyat dan ditujukan untuk melayani masyarakat yang ada di desa tersebut. Perpustakaan desa punya peran yang penting bagi warga desa untuk dapat meningkatkan pengetahuan mereka. Perpustakaan desa juga berperan menyediakan berbagai kebutuhan masyarakat terhadap informasi, Dengan informasi yang dimiliki, masyarakat dapat meningkatkan pengetahuan dan ketrampilannya dalam usaha meningkatkan taraf hidupnya. Dengan mengetahui akan pentingnya meningkatkan pengetahuan, diharapkan budaya literasi dapat mendukung masyarakat dalam mengembangkan potensi yang dimiliki dan dapat memperpaiki kesejahteraan mereka.

Sesuai Standar Nasional Indonesia, Fungsi perpustakaan desa atau kelurahan adalah [7]:

1. Mengembangkan jumlah koleksi perpustakaan;

2. Mengorganisasikan bahan perpustakaan;

3. Memberikan layanan berbagai bahan perpustakaan;

4. Menjadikan perpustakaan desa berfungsi sebagai tempat guna pembelajaran masyarakat sepanjang hidup;
5. Menjadikan perpustakaan sebagai pusat informasi, kegiatan, dan komunikasi masyarakat;

6. Menjadikan perpustakaan sebagai tempat rekreasi dan hiburan.

Agar Perpustakaan Desa dapat memenuhi fungsinya, ada beberapa faktor yang harus dapat dipenuhi sebuah perpustakaan Desa [5]. Dari berbagai standar yang ada, beberapa hal yang perlu dipenuhi adalah :

\section{Jumlah Koleksi}

Perpustakaan memiliki jumlah koleksi paling sedikit 1.000 judul.

\section{Jenis Koleksi}

Perpustakaan seharusnya memiliki jenis koleksi untuk anak, untuk remaja, untuk dewasa, koleksi untuk referensi, surat kabar dan majalah serta terdiri dari berbagai macam disiplin ilmu sesuai dengan kebutuhan masyarakat.

3. Pengolahan bahan perpustakaan.

Hendaknya dilakukan secara sederhana. Pengolahan administrasi perpustakaan dilakukan dengan pencatatan dalam buku induk, klasifikasi, dan deskripsi.

\section{Lokasi}

Hendaknya berada di tempat yang cukup strategis dan dapat dijangkau dengan mudah oleh masyarakat; dan status kepemilikannya pada pemerintah desa dengan legalitas hukum yang jelas.

5. Sarana Perpustakaan

Setiap perpustakaan hendaknya punya sarana guna penyimpanan koleksi, sarana kerja dan pelayanan perpustakaan; dan mempunyai sarana untuk dapat mengakses informasi minimal berbentuk katalog.

\section{METODE}

\subsection{Penyelesaian Masalah}

Untuk dapat memberikan solusi terhadap permasalahan yang ada, dilakukan berbagai langkah sebagai berikut :

1. Penambahan koleksi perpustakaan

2. Penataan koleksi

3. Penggunaan sistem pengelolaan perpustakaan

4. Sosialisasi perpustakaan desa kepada warga

Mutinda Teguh "Optimalisasi Perpustakaan Desa untuk Meningkatkan

Budaya Literasi di Desa Jatiadi, Kabupaten Probolinggo" 
Metode optimalisasi perpistakaan desa dapat digambarkan sebagai berikut :

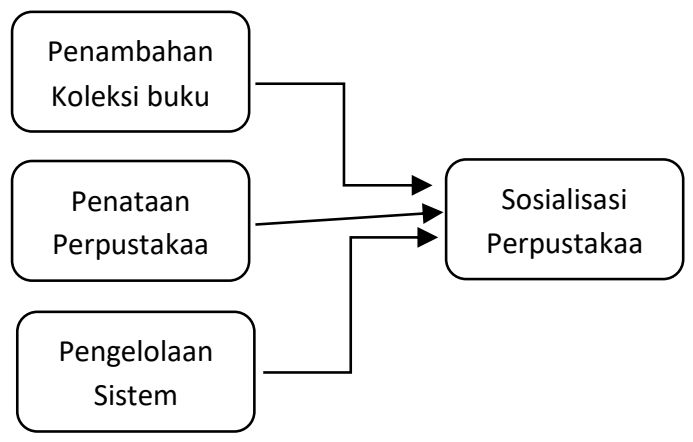

Gambar 1. Diagram Tahapan pelaksanaan

Pelaksanaan kegiatan pengabdian masyarakat ini dilakukan dengan tahapan sebagai berikut :

1. Inventarisasi permasalahan

2. Koordinasi rencana kegiatan

3. Mencari tambahan koleksi buku

4. Input data buku ke sistem

5. Penataan koleksi buku sesuai klasifikasi

6. Sosialisasi kepada masyarakat

\section{HASIL DAN PEMBAHASAN}

\subsection{Pelaksanaan Kegiatan}

Kegiatan pengabdian masyarakat ini dilakukan pada bulan Agustus hingga September 2019 dengan uraian berikut :

1. Inventarisasi Permasalahan

Perpustakaan Desa yang ada sudah mempunyai sekitar 700 koleksi buku dari berbagai jenis. Kondisi ruang perpustakaan belum tertata dengan baik dan rapi, buku buku yang ada belum dikelompokkan sesuai klasifikasi masing-masing. Katalog koleksi buku belum konsisten dan proses administrasi peminjaman masih dilakukan secara manual. Disamping itu Perpustakaan Desa Jatiadi juga mendapat hibah buku sebanyak 1.000 dan 2 unit Komputer serta software perpustakaan dari
Perpustakaan Nasional Indonesia, tetapi koleksi buku tersebut belum diinventarisir dan penggunaan software tersebut belum dijalankan.

2. Koordinasi rencana kegiatan

Sebelum pelaksanaan, dilakukan koordinasi pelaksanaan kegiatan yang dipimpin oleh koordinator kegiatan, dengan tujuan agar pelaksanaan kegiatan dapat berjalan baik dan lancar

3. Mencari tambahan koleksi buku Untuk menambah koleksi buku, Tim Pengabdian Masyarakat mencari donatur yang bersedia memberikan donasi berupa buku dari berbagai jenis sebagai tambahan koleksi perpustakaan. Dengan menghubungi berbagai pihak yang dianggap potensial, didapatkan sebanyak 70 buku dari berbagai jenis. Penyerahan buku hasil sumbangan donatur diserahkan kepada pengelola perpustakaan desa secara simbolis pada saat acara sosialilsasi Perpustakaan Desa kepada Masyarakat.

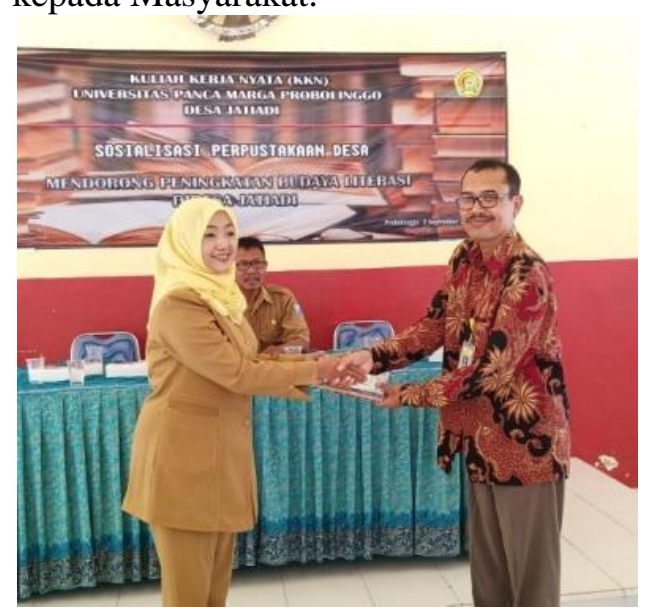

Gambar 2. Penyerahan Donasi Buku

\section{Input data buku ke sistem}

Buku-buku yang baru didapatkan, baik sumbangan dari donatur sebanyak 70 buku dan hibah dari Perpustakaan Nasional sebanyak 1.000 buku dimasukkan ke dalam daftar katalog dan dikelompokkkan sesuai jenis bukunya. Pada proses ini buku koleksi diberi kode sesuai klasifikasinya. Buku koleksi diberi kodem dicetak dan ditempel pada masing-masing buku. Disamping itu juga

Mutinda Teguh

"Optimalisasi Perpustakaan Desa untuk Meningkatkan

Budaya Literasi di Desa Jatiadi, Kabupaten Probolinggo" 
dilakukan input ke dalam software perpustakaan yaitu INLIS yang merupakan aplikasi perpustakaan dengan pengklasifikasian menggunakan sistem DDC (Dewey Decimal Classification) dan sudah diinstal ke dalam Personal Komputer yang juga merupakan bantuan dari Perpustakaan Nasional Indonesia.

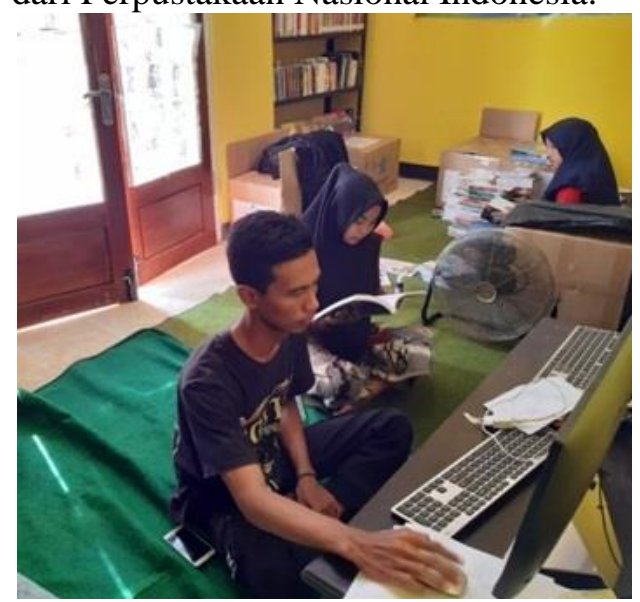

Gambar 3. Proses Entri Data Buku

\section{Penataan Koleksi sesuai penggolongan} Selanjutnya setelah buku dimasukkan ke dalam katalog, buku-buku tersebut ditata secara rapi di rak buku yang ada sesuai klasifikasinya. Penataan buku ini akan sangat bermanfaat dan mem-perlancar proses pencarian buku.

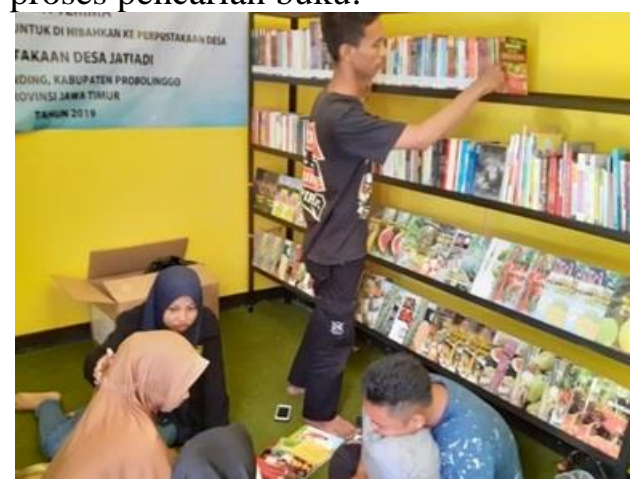

Gambar 4. Penataan Koleksi Buku

6. Sosialisasi kepada masyarakat

Setelah selesai proses pembenahan perpustakaan, langkah selanjutnya ialah dengan melakukan kegiatan sosialisasi tentang keberadaan dan pengtingnya perpustakaan desa kepada masyarakat. Kegiatan dilakukan dengan mengundang para kepala dusun dan masyarakat dengan berbagai latar belakang, dengan harapan mengetahui keberadaan perpustakaan desa dan dapat memanfaatkannya untuk menambah pengetahuan dan informasi yang dibutuhkan.

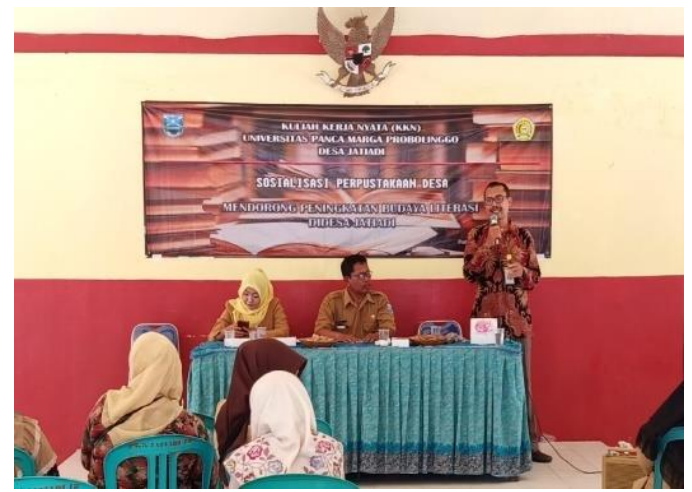

Gambar 5. Sosialisasi perpustakaan desa

\subsection{Dampak yang diharapkan}

Kegiatan ini dilakukan dengan harapan adanya peningkatan budaya literasi pada masyarakat melalui optimalisai perpustakaan desa. Dengan keberadaan perpustakaan desa yang memadai, dan sosialisasi yang telah dilakukan kepada masyarakat, diharapkan adanya budaya literasi. Diharapkan masyarakat dapat memanfaatkan perpustakaan desa untuk memenuhi kebutuhan mereka terhadap pengetahuan dan informasi yang dapat meningkatkan ketrampilan sesuai yang mereka butuhykan dan dapat meningkatkan kesejahteraan dan taraf hidup mkereka. Roadmap Pengabdian Masyarakat ini dapat digambarkan sebagai berikut :

Mutinda Teguh "Optimalisasi Perpustakaan Desa untuk Meningkatkan

Budaya Literasi di Desa Jatiadi, Kabupaten Probolinggo" 


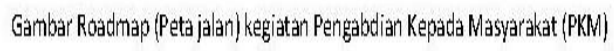

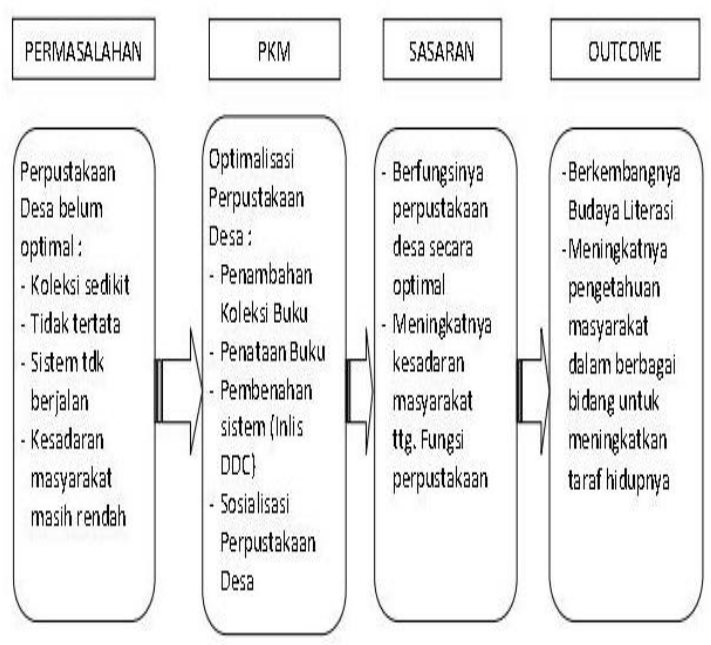

Gambar 6. Roadmap Kegiatan Pengabdian

\section{KESIMPULAN}

Keberadaan Perpustakaan Desa yang cukup representatif akan sangat bermanfaat bagi masyarakat dalam upaya memperoleh informasi dan pengetahuan yang dibutuhkan yang dapat upaya untuk meningkatkan taraf hidup mereka. Melalui kegiatan Pengabdian Masyarakat ini, keberadaan perpustakaan di Desa Jatiadi semakin baik dengan adanya tambahan koleksi buku, penataan dan perbaikan sistem pengelolaan perpustakaan yang lebih baik, ditambah lagi dengan adanya sosialisasi kepada masyarakat tentang keberadaan perpustakaan desa dan manfaat yang bisa diperoleh. Diharapkan dengan kegiatan ini budaya literasi masyarakat dapat meningkat sehingga mereka mendapatkan pengetahuan dan informasi yang dibutuhkan dalam rangka mening-katkan kualitas dan taraf hidupnya dicapai.

\section{SARAN}

Upaya yang telah dilakukan untuk mengoptimalkan fingsi perpustakaan desa ini masih jauh dari sempurna, untuk itu diharapkan upaya ini dapat dilanjutkan dengan kegiatan pengabdian masyarakat yang akan datang agar upaya untuk meningkatkan bidaya literasi bagi masyarakat ini dapat berkesinambungan dan juga diharapkan agar pihak pengelola perpustakaan desa dapat memelihara dan menjaga agar perpustakaan desa ini dapat dimanfaatkan seoptimal mungkin oleh masyarakat.

\section{UCAPAN TERIMA KASIH}

Puji Syukur kita haturkan ke hadirat Allah atas selesainya kegiatan pengabdian kepada masyarakat ini, tidak lupa, kami juga mengucapkan terima kasih kepada pihak yang telah membantu atas terselenggaranya kegiatan ini, diantaranya :

1. Bapak Rektor Universitas Panca Marga Probolinggo

2. Ketua LPPM Universitas Panca Marga Probolinggo

3. Kepada Desa serta para aparat desa Jatiadi Kecamatan Gending Kabupaten Probolinggo

4. Mohammad Yusuf, Koordinator Tim Peningkatan Budaya Literasi KKN Universitas Panca Marga Probolinggo tahun 2019.

5. Pihak-pihak yang telah mendukung berjalannya kegiatan ini yang tidak dapat kami sebutkan satu-persatu.

\section{REFERENSI}

[1] Iriantara, Yosal. 2009. Literasi Media: Apa, Mengapa, dan Bagaimana, Simbiosa Rekatama Media, Bandung.

[2] Faizah, Dewi Utama dkk. 2016. Panduan Gerakan Literasi Sekolah Di Sekolah Dasar, Direktorat Jendral Pendidikan Dasar Dan Menengah Kementrian Pendidikan Dan Kebudayaan, Jakarta.

[3] Atmazaki, dkk, 2017. Panduan gerakan Literasi Nasional, Kementerian Pendidikan dan Kebudayaan, Jakarta.

[4] UNDANG-UNDANG REPUBLIK INDONESIA NOMOR 43 TAHUN 2007 TENTANG PERPUSTAKAAN

[5] Peraturan Kepala Perpustakaan Nasional Republik Indonesia Nomor 6 Tahun 2017 tentang Standar Nasional Perpustakaan Desa / Kelurahan

[6] Darmono, 2016. Standar Pengelolaan

Mutinda Teguh "Optimalisasi Perpustakaan Desa untuk Meningkatkan

Budaya Literasi di Desa Jatiadi, Kabupaten Probolinggo" 
perpustakaan desa/KelurahanSesuai Dengan SNP 005:2011, Universitas Negeri Malang, Malang.

[7] Standar Nasional Indonesia Perpustakaan Desa/Kelurahan No. SNI7696; 2010, Badan Standarisasi Nasional, Jakarta. 